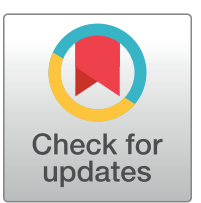

CORRECTION

\title{
Correction: Social, demographic, health care and co-morbidity predictors of tuberculosis mortality in Amazonas, Brazil: a multiple cause of death approach
}

\author{
Vanderson de Souza Sampaio, Maria Gabriela de Almeida Rodrigues, Leila Cristina \\ Ferreira da Silva, Daniel Barros de Castro, Patrícia Carvalho da Silva Balieiro, Ana \\ Alzira Cabrinha, Antonio José Leal Costa
}

There are errors in the Funding statement. The correct Funding statement is as follows: This work was supported by grant Programa Estratégico de Ciência, Tecnologia \& Inovação nas Fundações de Saúde-PECTI/AM/SAÚDE, Carta Convite 001/2014 and PAPAC, EDITAL N ${ }^{\circ}$ 005/2019, both of Fundação de Amparo à Pesquisa do Estado do Amazonas-FAPEAM. The funders had no role in study design, data collection and analysis, decision to publish, or preparation of the manuscript.

\section{Reference}

1. Sampaio VdS, Rodrigues MGdA, Silva LCFd, Castro DBd, Balieiro PCdS, Cabrinha AA, et al. (2020) Social, demographic, health care and co-morbidity predictors of tuberculosis mortality in Amazonas, Brazil: a multiple cause of death approach. PLoS ONE 15(1): e0218359. https://doi.org/10.1371/ journal.pone.0218359 PMID: 31995562

Citation: Sampaio VdS, Rodrigues MGdA, Silva LCFd, Castro DBd, Balieiro PCdS, Cabrinha AA, et al. (2020) Correction: Social, demographic, health care and co-morbidity predictors of tuberculosis mortality in Amazonas, Brazil: a multiple cause of death approach. PLoS ONE 15(2): e0229749. https://doi.org/10.1371/journal.pone.0229749

Published: February 21, 2020

Copyright: @ 2020 Sampaio et al. This is an open access article distributed under the terms of the Creative Commons Attribution License, which permits unrestricted use, distribution, and reproduction in any medium, provided the original author and source are credited. 